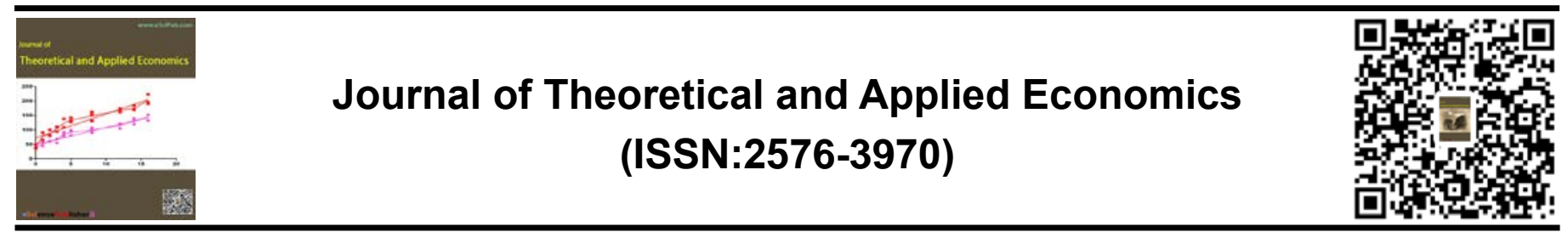

\title{
Rationale and risks of non-audit services
}

\section{You Yu}

\begin{abstract}
With changing conditions of the financial environment, relative issues of non-audit services still require further developments and researches, concerning their rationale and risks that can be *Correspondence to Author: You Yu admitted so far, and influences of latest regulations. Here the rationale and risks of NAS were investigated through summarizing prior studies. Some researchers believe that there is a trade-off effect between advantages and disadvantages of NAS, therefore, it can be accordingly concluded that there is at least net effect in NAS's downsides and upsides, the rationality of NAS can be prove based on this sight. However, many latest researches tend to believe NAS has adverse impacts.

E-mail:y u y o@tcd.ie
\end{abstract}

Keyword: Rationale, risks, non-audit services, advantages, disadvantages

\section{eSciencePublisher 2 \\ eSciPub LLC, Houston, TX USA. \\ Website: http://escipub.com/}


With changing conditions of the financial environment, relative issues of non-audit services still require further developments and researches, concerning their rationale and risks that can be admitted so far, and influences of latest regulations. Here the rationale and risks of NAS were investigated through summarizing prior studies. Some researchers believe that there is a trade-off effect between advantages and disadvantages of NAS, therefore, it can be accordingly concluded that there is at least net effect in NAS's downsides and upsides, the rationality of NAS can be prove based on this sight. However, many latest researches tend to believe NAS has adverse impacts.

\section{The Rationale for NAS}

\section{Knowledge Spillover Effects}

Tang (2012) explained knowledge spillover effect that when the auditor provides both audit service and NAS for the client, their experiences and understandings gathered from carrying NAS can be helpful to audit works, like simplifying audit procedures, thus reduce working time on auditing. The paper written by Tepalagul and Lin in 2014 also mentioned knowledge spillover effect, they described basic motivations on NAS hold by different groups of people, this is also the reason why NAS still exists. For accountancy firms' perspective, it is profitable to undertake NAS, which is also perceived as favorable for risk assessment and auditors' knowledge base. General perception is that clients are incentive to purchase NAS because of reduced expenses and better service quality. And different conclusions of previous researches are shown in the paper, which give directions to develop NAS. Beck and Wu (2006) aroused a concept called business advisory effect which means that the management's decision can be affected when receiving NAS. The business advisory effect can develop auditor's insight to understand the company's operating rationale, thus to improve auditing quality. They found that the business advisory effect and NAS are mutual-influenced, because performing NAS accumulates auditors' experiences and skills, so they can provide more precise managerial suggestions to clients, which leads to more complicated financial situation in companies, thus the more professional auditing procedures are required.

Chan et al. (2012) and Joe et al. (2007) also proved the presence of knowledge transfer influence. Chan et al. concluded that non-audit fee a has positive correlation with auditing fees. And Joe et al. (2007) explained knowledge transfer effect, which means that NAS are favorable for risk evaluation and auditing assurance. To achieve this goal, auditors' related capacities are required. For example, they need to recognize connections between audit and NAS and know the appropriate way to boost them together. Through testing designated hypotheses, they concluded that the condition of knowledge transfer influence is that the auditor is carrying on both audit and NAS.

\section{Synergy Effects}

Prior studies conclude synergy effects led by NAS that are beneficial to client companies. With regard to the improvement in the quality of financial report, Dhaliwal et al. in 2008 explored the relationship between auditing fees including NAS charge and the cost of debt, researchers perceived that the cost of debt can reflect a company's financial report quality. As a result, they discovered that auditing fees' moving direction is the same as the movement of companies' cost of debt, in other words, NAS improved financial report quality, but this situation only exists in investment-grade companies. Companies are possible to rise its wealth by paying more auditing fees, since more costs consumed on the company's financial report, the financial report can be regarded as more reliable and fair, thus better bond rating can be gained. Palmrose et al. (2004) set the financial report restatement as the measurement of auditing failure, finally, they concluded that companies who took tax services tend to be free of restatement exposures.

For auditors' perspectives, NAS are potential to improve their incomes earned through providing audit services. Halperin and Lai (2014) briefly 
focused on tax service fees because they think that tax services more closely relate to audit services. They found that tax service fees have the positive relationship with audit fees, this is in accordance with many former studies. Their additional test shows that the company pay more audit fees to auditors who also provide NAS than who only offer audit services to this company. One potential explanation can be auditors need to receive compensations for offering 2 or more types of services to the client, especially it was regarded rather risky in the pre-SOX period. And this result encourages the cross-selling of audit services and NAS.

\section{More Favorable Position of Auditors}

Halperin and Lai (2014) found that accountancy firms' joint provision of audit and non-audit services is also associated with their client's satisfactions with their services. If clients feel satisfied with services they purchased, they are more likely to apply other services from the same accountancy firm. Thus NAS are potential to help accountancy firms to retain their clients. They also discovered that when the client purchases tax services from the auditor, there is a stable bound between them, the client does not tend to switch the auditor easily.

Tax services sometimes would be particularly concentrated by researchers, because most tax services were permitted by SOX in 2002 with the recognition that NAS threat auditors' independence and auditing outcomes. In the response, Danlia (2008) found no evidence that tax services hurt auditors' independence, and no relation between auditing fees and adverse concerns. This finding is in favor of improving the image of auditors in the financial environment.

\section{Risks of NAS}

\section{Conflicts of Interest}

There are also some previous studies focused on downsides of NAS, Beaulieu and Reinstein (2010) presented a scenario about the conflict of interest. For managers who owns the company, they prefer to capture the benefits of NAS, while for external managers, they are more constrained to take NAS concerning the underlying impairment of auditor independence. Parkash and Venable (1993) claimed that for shareholders who own the company tend to utilize upsides of NAS, but for managers, they are less possible to apply NAS considering the agency effects. Because of mandatory requirements, companies need to expose their audit and non-audit service purchases. Abbott et al. (2011) concluded that with the influence of SEC regulation in terms of auditor charge exposures, companies who are seeking capital are more constrained to apply NAS. But for shareholders who manage the company are willing to pay for NAS.

Eilifsen and Knivsfla (2013) measured the result of NAS at investors' prospects, they selected the return of companies' stock as the metric to evaluate the necessity of NAS, concerning the influence of existing regulations. A problem was aroused during research process is that if auditors find deficiencies in client company's financial accounts, they may slur them because they also take responsibility for NAS. Thus investors would be more prudent when regarding the concern of NAS, but this can be lessened by issuing relevant laws. In addition, Nelson (2006) believe that there is a trade-off effect in auditors' incentives to perform NAS, on one hand, auditors may compromise in order to satisfy and remain clients, on the other hand, they also afraid of reputation loss and legislation risks. The original motivation for the author is to argue a prior study which indicated that recent transformations shown no usefulness to alleviate conflicts of interest in auditing.

The Impairment of Auditors' Independence and Public Impression

The latest researches tend to indicate the harm of NAS in auditors' independence. Lee et al. (2009) think auditors' multiple roles have negative impacts on their independence. To be specific, when auditors carry on NAS for clients, they are working as an advisor to the management, but they are also an attester to the financial statement at the same time. They also 
focused on auditing expectation gap and denoted that NAS is one of the reasons. But they assumed possible solution that if the accordance between expected auditing outcome and actual auditing performance increased, the unreliability raised by public towards NAS can be alleviated. Causholli et al. (2015) also concerned about adverseness of the sale of NAS, as the purchase of NAS by clients is seen as the measurement of audit partner's performance. Researchers perceived that this incentive especially hurt auditor's independence in the future, as this opinion has accordance with Causholli et al.'s (2014) hypothesis that accountancy firm's NAS effort is the most significant factor to impair auditor's independence. In contrast, Ashbaugh et al. (2003) found that non-audit fees have the positive association with restatements, and nonaudit fees have no relation to auditors' independence.

Beaulieu and Reinstein (2010) reviewed mixed perspectives for auditing independence issues, and particularly focused on beliefs held by various groups, like auditors in big and small scale firms, auditors and non-auditors, which is helpful in investigating the nature of NAS. They also provided a view on how accounting professions think of independence issues in NAS. By testing hypotheses about people's common sense about NAS, they predicted that auditors in bigger accountancy firm are more tend to think NAS threat independence than auditors in small firms.

Additionally, Brandon et al. (2004) used bond rating as the magnitude to examine the association of bond rating and NAS, because the bond rating is according to companies' audited financial states, thus the auditing quality can be reflected by the level of bond rating. They summarized that the level of outsourced NAS has the negative relationship with the bond rating, thus the worse bond rating is accompanied with more NAS fees.

Duh et al. in 2007 aimed to explore whether NAS threat auditors' independence, and whether the level of independence improved in Taiwan after the scandal of Procom in 2004, as this event has aroused public concern to auditor independence issues. Researchers denied the effectiveness of discretionary accruals to measure auditing independence level, instead to use the deviation between audited earnings and estimate earnings, regressed with the auditing fee ratio. They discovered that additional auditing modification is considerably negative with auditing fee ratio before Procom sandal compares to the event happened. Then it can be presumed that the incentive of management manipulation decreased under the tighter regulatory atmosphere. Based on regression results, the greater amount of auditing adjustments indicates higher independence and the independence of auditor has been strengthened after Procom event, because macro-financial environment became favorable to discipline their actions.

With the concentration on relative legislations and regulations to guarantee auditors' independence, some studies shown their support on regulatory outcomes. Nelson (2006) also admitted the effectiveness of regulations to secure auditors' independence like SEC's independence standard. Besides, Danlia (2008) concentrated on tax services, and their researched targets are bankrupt companies. The author approved the effectiveness of relative legislations aiming to constrain auditors' behaviors.

\section{Audit and Non-Audit Fees by Industry}

The industry of auditee is an important factor to determine audit fees. Mitra (2007) targeted on oil and gas industry because of its complexity and unique operating characteristics. The study indicated that it is more likely for audits to sell NAS for industries with great complexity, which encourages auditors to strength their industryspecific knowledge. The second feature relates to the situation that mandated disclosures are required in oil and gas industry thus managements are more incentive to manipulate financial outcomes to meet regulatory requirements. As a result, auditors could be 
decoyed by higher remuneration to conceal information that is detrimental to managements. Additionally, revenues are often fluctuated in this industry because of changes in natural conditions and the relationship between supply and demand. In response, auditors who are familiar in this industry are expected to carry out supplemental techniques to assist their clients, and this is seen as an ideal scenario for auditors to remain the independence. But their conclusions did not support the concern that NAS threats auditors' independence aroused by the SEC.

Hay et.al. (2006) inferred that financial institutions and utility companies' capital structures are dissimilar with companies in other industries, and they are easier to be audited. Manufacturing enterprises have more extensive inventories and receivables, which leads to higher audit costs. In contrast, Fields et al. (2003) concluded that banks are charged higher audit fees through examining 277 research objectives in the U.S. banking industry, the reason is that banks have more complicated accounts with higher auditing risks.

As mentioned in the paper written by Fuentes et al. (2009), in 2012, audit fees in retailing, metals, transportation, communication and other services industries constitute more than $85 \%$ of total fees they paid. The proportion in glass and construction industries are around $73 \%$ and $60 \%$ respectively. Additionally, property and other manufacturing sectors like food, drinks, tobacco, textiles and printing, pay nearly half of total expenditures on auditing, and non-audit fees took up $50 \%$ of total audit expenses. In energy water, mass media and new technology industries, companies pay more than $60 \%$ expenses on NAS. Thus the amount of audit fee and non-audit fee varies in different industries, and audit fees paid by new technology companies significantly overweigh the amount paid by retailing companies.

\section{Further Analysis on Rationale \& Risks of NAS}

For gaining deeper insight of benefits and weakness of NAS, the human-coded method is applied in this part, even if the computer-aided method is also applicable, like counting the number of keywords in texts by software and calculating the frequency to get the final ratio. Its weakness is that computer software purely records the frequency of keywords, neglecting the influence of textual environment and the same meaning in different expressions, thus the ideal procedure is classifying previous evaluations of NAS manually, according to codes (advantage \& disadvantage). Then to compare and analyze these two categories, and finally formulate an acceptable conclusion. Papers are selected after the year 2000 in order to integrate the last financial conditions over around 2 decades. Content analysis enables us to gain a wider theory base, because additional previous studies mentioned in papers that are selected for the literature review are also examined, thus the research scale is actually exceeded.

3 advantages and 2 disadvantages of NAS are summarized and shown in the following paragraph, these contents generalize existed academic opinions so far, which can be seen as the integration of the literature review. However, there is a problem in this procedure that the frequency of statements can be calculated repeatedly, because a paper can be cited by different authors. But this does not cause very destructive effects for the study results, because the conclusion is not only relied on the figure of frequencies, the behind tendency is considered more significantly, if one opinion is cited by more people, it can be seen as more reliable and acceptable.

\section{Advantages:}

\section{Knowledge spillover effects}

Decreasing the complexity of auditing. Accountancy firms can employ professions with diversified capacities, thus to decrease the dependence of external specialists.

\section{Synergy effect}


Knowing better about clients, reducing auditing risks and costs and increasing audit efficiency.

More favorable position

NAS underlined the dependence of clients on auditors, thus auditors are able to gain a beneficial position in the coordination and to solve conflicts. But they need to concern the exposure of reputation losses.

\section{Disadvantages:}

\section{Conflicts of interest}

Auditors cannot provide objective judgments for clients when they also work as their consultants. When the revenue of NAS exceeds that of auditing services, auditing service quality may be impaired.

\section{Conflicts in auditors' public impression}

The public tends to perceive that auditors are incentive to compromise with their clients, because it is hard for auditors to keep an independent form with clients when they are carrying NAS, even though they are essentially independent. Thus the effectiveness of audit report is impaired.

The concept of independence can be split into 2 respects, independence of mind and independence in appearance, the meaning of these 2 explanations are similar to what are mentioned on former texts that independence in essential and in form. According to the International Federation of Accountants' (IFAC), 'independence in mind' stands for the state of mind that guarantee the integrity of conclusions that made without any interference and compromise. 'Independence in appearance' refers to the significance of the participation of the third party, because the third party is perceived as non-interest-related entity thus its objectivity and skepticism can be trusted by the public. It is commonly believed that accountancy firms are the third party standing between the authority and their clients, but NAS seems to disturb this perception, thus they are questioned on the 'Independence in appearance' issue.

Papers that mentioned in the literature review are continually included in the research sample, to find opinions explicitly relating to strengths and weakness of NAS, the research does not consider sentences that do not show any particular tendency. The research process for this question can be recorded visually by tables below, which shows numbers of statements mentioned in previous articles, including their own statements, common sense approved by professions, and relative conclusions they found in previous studies. According to the frequency of statements about strengths and weakness of NAS, the study could finally get conclusions, and the amount of figures can show the extent of agreement held by academics for each strength or weakness. As for standpoints hold by professionals and authors are not suitable to be measured statistically, thus this study applies the sigh " $\checkmark$ " as the indication. But in favor of getting a visible result, each tendency of authors and professionals will stand for one vote for agreement of NAS's advantages or disadvantages.

\section{Table 1 Further analysis of the literature review on NAS}

\begin{tabular}{|l|l|l|l|}
\hline & \multicolumn{3}{|l|}{ Tepalagul (2015) } \\
\cline { 2 - 4 } & $\begin{array}{l}\text { Literature } \\
\text { Review }\end{array}$ & Professionals & Findings \\
\hline Advantage 1 & 2 & $\checkmark$ & \\
\hline Advantage 2 & 1 & & \\
\hline Advantage 3 & & & \\
\hline Pro & 4 & & \\
\hline Disadvantage 1 & 4 & & \\
\hline
\end{tabular}


You Yu, JTAE, 2017; 1:4

\begin{tabular}{|l|l|l|l|}
\hline Disadvantage 2 & 4 & & \\
\hline Anti & 8 & & \\
\hline
\end{tabular}

\begin{tabular}{|l|l|l|l|}
\hline & \multicolumn{2}{|l|}{ Duh (2007) } & Findings \\
\cline { 2 - 4 } & $\begin{array}{l}\text { Literature } \\
\text { Review }\end{array}$ & Professionals & \\
\hline Advantage 1 & 2 & & \\
\hline Advantage 2 & & & \\
\hline Advantage 3 & 3 & & $\checkmark$ \\
\hline Pro & 5 & & \\
\hline Disadvantage 1 & 2 & & \\
\hline Disadvantage 2 & & & \\
\hline Anti & 3 & & \\
\hline
\end{tabular}

\begin{tabular}{|l|l|l|l|}
\hline & \multicolumn{2}{|l|}{ Lee (2006) } & Findings \\
\cline { 2 - 4 } & $\begin{array}{l}\text { Literature } \\
\text { Review }\end{array}$ & Professionals & \\
\hline Advantage 1 & & & \\
\hline Advantage 2 & & & \\
\hline Advantage 3 & & & $\checkmark$ \\
\hline Pro & 0 & & \\
\hline Disadvantage 1 & 5 & & \\
\hline Disadvantage 2 & & & \\
\hline Anti & 6 & & \\
\hline
\end{tabular}

\begin{tabular}{|l|l|l|l|}
\hline & \multicolumn{2}{|l|}{ Beck (2006) } & Findings \\
\hline & $\begin{array}{l}\text { Literature } \\
\text { Review }\end{array}$ & Professionals & \\
\hline Advantage 1 & 5 & & $\checkmark$ \\
\hline Advantage 2 & & & \\
\hline Advantage 3 & & & $\checkmark$ (trade-off) \\
\hline Pro & 6 & & \\
\hline Disadvantage 1 & & & \\
\hline Disadvantage 2 & & & \\
\hline Anti & 1 & & \\
\hline
\end{tabular}

\begin{tabular}{|l|l|l|l|}
\hline & \multicolumn{2}{|l|}{ Chan (2012) } & Findings \\
\cline { 2 - 4 } & $\begin{array}{l}\text { Literature } \\
\text { Review }\end{array}$ & Professionals & $\checkmark$ \\
\hline Advantage 1 & 9 & & \\
\hline Advantage 2 & 1 & & \\
\hline
\end{tabular}


You Yu, JTAE, 2017; 1:4

\begin{tabular}{|l|l|l|l|}
\hline Advantage 3 & \multicolumn{3}{|l|}{} \\
\hline Pro & 11 & & \\
\hline Disadvantage 1 & & & \\
\hline Disadvantage 2 & & & \\
\hline Anti & 0 & & \\
\hline
\end{tabular}

\begin{tabular}{|l|l|l|l|}
\hline & \multicolumn{2}{|l|}{ Joe (2007) } & Findings \\
\cline { 2 - 4 } & $\begin{array}{l}\text { Literature } \\
\text { Review }\end{array}$ & Professionals & \\
\hline Advantage 1 & 9 & $\checkmark$ & $\checkmark$ \\
\hline Advantage 2 & & & \\
\hline Advantage 3 & & & \\
\hline Pro & 11 & $\checkmark$ & \\
\hline Disadvantage 1 & 2 & & \\
\hline Disadvantage 2 & & & \\
\hline Anti & 3 & & \\
\hline
\end{tabular}

\begin{tabular}{|c|c|c|c|}
\hline & \multicolumn{3}{|c|}{ Robinson (2008) } \\
\hline & $\begin{array}{l}\text { Literature } \\
\text { Review }\end{array}$ & Professionals & Findings \\
\hline Advantage 1 & 3 & & \\
\hline \multicolumn{4}{|l|}{ Advantage 2} \\
\hline \multicolumn{4}{|l|}{ Advantage 3} \\
\hline Pro & \multicolumn{3}{|l|}{3} \\
\hline Disadvantage 1 & 4 & $\checkmark$ & \\
\hline Disadvantage 2 & & $\checkmark$ & \\
\hline \multirow[t]{3}{*}{ Anti } & \multicolumn{3}{|l|}{6} \\
\hline & \multicolumn{3}{|c|}{ Eilifsen (2013) } \\
\hline & $\begin{array}{l}\text { Literature } \\
\text { Review }\end{array}$ & Professionals & Findings \\
\hline Advantage 1 & 6 & $\checkmark$ & Net effect \\
\hline \multicolumn{4}{|l|}{ Advantage 2} \\
\hline \multicolumn{4}{|l|}{ Advantage 3} \\
\hline Pro & \multicolumn{3}{|l|}{7} \\
\hline Disadvantage 1 & 4 & $\checkmark$ & \\
\hline \multicolumn{4}{|l|}{ Disadvantage 2} \\
\hline$\overline{\text { Anti }}$ & \multicolumn{3}{|l|}{5} \\
\hline
\end{tabular}

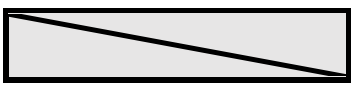

Halperin (2014) 
You Yu, JTAE, 2017; 1:4

\begin{tabular}{|l|l|l|l|}
\hline & $\begin{array}{l}\text { Literature } \\
\text { Review }\end{array}$ & Professionals & Findings \\
\hline Advantage 1 & 2 & & \\
\hline Advantage 2 & & & \\
\hline Advantage 3 & & & \\
\hline Pro & 2 & & \\
\hline Disadvantage 1 & 1 & & \\
\hline Disadvantage 2 & & & \\
\hline Anti & 1 & & \\
\hline
\end{tabular}

\begin{tabular}{|l|l|l|l|}
\hline & \multicolumn{3}{|l|}{ Causholli (2015) } \\
\hline & $\begin{array}{l}\text { Literature } \\
\text { Review }\end{array}$ & Professionals & Findings \\
\hline Advantage 1 & & & \\
\hline Advantage 2 & 1 & & \\
\hline Advantage 3 & & & \\
\hline Pro & 1 & & $\checkmark$ \\
\hline Disadvantage 1 & 1 & & $\checkmark$ \\
\hline Disadvantage 2 & & & \\
\hline Anti & 3 & & \\
\hline
\end{tabular}

\begin{tabular}{|l|l|l|l|}
\hline & \multicolumn{3}{|l|}{ Causholli (2014) } \\
\hline & $\begin{array}{l}\text { Literature } \\
\text { Review }\end{array}$ & Professionals & Findings \\
\hline Advantage 1 & & & \\
\hline Advantage 2 & & & \\
\hline Advantage 3 & & & \\
\hline Pro & 0 & & $\checkmark$ \\
\hline Disadvantage 1 & 3 & & $\checkmark$ \\
\hline Disadvantage 2 & & & \\
\hline Anti & 5 & & \\
\hline
\end{tabular}

\begin{tabular}{|l|l|}
\hline & Sum \\
\hline Advantage 1 & 44 \\
\hline Advantage 2 & 3 \\
\hline Advantage 3 & 3 \\
\hline Pro & 50 \\
\hline Disadvantage 1 & 34 \\
\hline Disadvantage 2 & 7 \\
\hline Anti & 41 \\
\hline
\end{tabular}


To sum up figures for each item among 11 papers, which are considered as the most relevant to rationale and risks of NAS. The final result is shown in the chart above. More statements are in favor of advantages of NAS, the figure of disadvantages also cannot be ignored and there is not a huge difference between them. Advantage 1 and disadvantage 1 are shown to be more widely acceptable, and generally, every viewer in terms of this topic cannot deny existences of these 2 statements. Some researchers believe that there is a tradeoff effect between advantages and disadvantages of NAS, therefore, it can be accordingly concluded that there is at least net effect in NAS's downsides and upsides, the rationality of NAS can be prove based on this sight. However, many latest researches tend to believe NAS has adverse impacts.

\section{References}

Abbott, L. J., Parker, S., Peters, G. F. (2011). Does mandated disclosure induce a structural change in the determinants of nonaudit service purchases? Auditing: A Journal of Practice \& Theory, 30(2), 51-76.

Ashbaugh H, Lafond R, Mayhew B (2003) Do nonaudit services compromise auditor independence? Further evidence. Account Rev 78:611-639.

Beaulieu, P., Reinstein, A. (2010). Belief perseverance among accounting practitioners regarding the effect of non-audit services on auditor independence. Journal of Accounting and Public Policy, 29(4), 353-373.

Beck, P. J., Wu, M. G. (2006). Learning by Doing and Audit Quality. Contemporary Accounting Research, 23(1), 1-30. doi:10.1506/axu4-q7q93yab-4qe0

Brandon, D. M., Crabtree, A. D., Maher, J. J. (2004). Nonaudit fees, auditor independence, and bond ratings. Auditing: A Journal of Practice \& Theory, 23(2), 89-103.

Chan, L., Chen, T., Janakiraman, S., Radhakrishnan, S. (2012). Reexamining the relationship between audit and nonaudit fees: Dealing with weak instruments in two-stage least squares estimation. Journal of Accounting, Auditing \& Finance, 2, 299-324.

Dhaliwal, D. S., Gleason, C. A., Heitzman, S., Melendrez, K. D. (2008). Auditor fees and cost of debt. Journal of Accounting, Auditing \& Finance, 23, 1-22.

Duh, R., Lee, W., Hua, C. (2007). Non-audit service and auditor independence: An examination of the Procomp effect. Rev Quant Finan Acc Review of Quantitative Finance and Accounting, 32(1), 33-59.

Eilifsen, A., Knivsfla ${ }^{\circ}$ K. H. (2013). How increased regulatory oversight of nonaudit services affects investors' perceptions of earnings quality. Auditing: A Journal of Practice \& Theory, 32(1), 85-112.

Fuentes, C., Pucheta-Martínez, M. C. (2009). Auditor independence, joint determination of audit and non-audit fees and the incidence of qualified audit reports. Academia. Revista Latinoamericana De Administración, 63-92.

Joe, J. R., Vandervelde, S. D. (2007). Do auditorprovided nonaudit services improve audit effectiveness. Contemporary Accounting Research, 24, 467-487.

Kinney, W. R., Palmrose, Z., Scholz, S. (2004). Auditor independence, non-audit services, and restatements: Was the U.S. government right? Journal of Accounting Research, 42, 561-588.

Lee, T. H., Ali, A. M., Bien, D. (2009). Towards an Understanding of the Audit Expectation Gap. The Icfai University Journal of Audit Practice.

Mitra, S. (2007). Non-audit Service Fees and Auditor Independence: Empirical Evidence from the Oil and Gas Industry. Journal of Accounting, Auditing \& Finance

Nelson, M. W. (2006). Ameliorating Conflicts of Interest in Auditing: Effects of Recent Reforms On Auditors and Their Clients. Academy of Management Review, 31(1), 30-42.

Parkash M., Venable, (1993), Auditee incentives for auditor independence: The case of non-audit services, The Accounting Review, 68, pp. 113-33.

Tang, Q., Chen, H., Lin, Z. (2011). How to Measure Country Level Financial Reporting Quality? SSRN Electronic Journal SSRN Journal. doi:10.2139/ssrn.2114810

Tepalagul, N., Lin, L. (2014). Auditor Independence and Audit Quality: A Literature Review. Journal of Accounting, Auditing \& Finance, 30(1), 101-121.

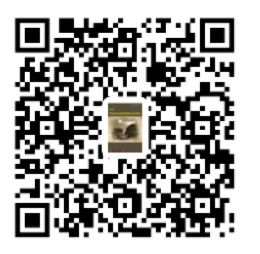

Http://escipub.com/journal-of-theoretical-applied-economics/ 